\section{Creativity as the Main Factor for Organizations" Success: Theoretical Approach}

\section{Jurgita Baryniene, Berta Dauknyte}

Kaunas University of Technology

\section{$\Gamma$} Crossef http://dx.doi.org/10.5755/j01.eis.0.9.12810

In recent decades drastic changes of economic activity conditions are observed. Global transformations and rapid development of information and communication technologies (ICT) have resulted in emergence of knowledge economy where the added value is created on the basis of knowledge. Due to this reason, business organisations operating under such conditions must increasingly focus on innovations and innovative processes which would guarantee them a competitive advantage. Companies which do not create innovations or at least do not introduce innovations in their activity, is quickly pushed out of today market.

In the last century the creation of innovations was an accidental process. However today it is overwhelmingly a targeted activity. In today's society innovations are understood as vital for social and economic development. Innovations do not come up by themselves. Creativity is an important condition for innovations to occur. Although the concept of creativity is often used in both the scientific and public discourse, the boundaries of this concept are often unclear. Scientists emphasize the complexity and multidimensity of this concept.

For some businesses, creativity is an important factor: clients in advertising agencies require a creative advertisement; architects, designers also often have to create an exclusive and unique creation. However, in other business areas creative thinking is not such a matter of course. Although the majority of world business organizations, while declaring the values, use such words as "innovations", "creativity", "new and smart thinking", in reality they remain only the statements of declarative nature. Therefore the main problematic question arises: how the creativity can contribute to the success of business organisations.

The aim of this paper is to determine the directions of use of creativity in business organisations. In order to achieve this aim, the following objectives have been set: with reference to scientific literature to present evolution of the concept of creativity; to cristalyzed out contemporary concept of creativity; to identify the factors which encourage the development of creativity in organisations.

The research method used: in-depth analysis of scientific literature, synthesis.

The main results and conclusions of the article are: revealed the concept of creativity and its importance in nowadays organizations; constructed the model of factors which influence the expression of creativity in business organizations.

KEYWORDS: creativity, innovations, business organizations, model, factors.

\section{EIS 9/2015}

Creativity as the Main Factor for Organizations" Success: Theoretical Approach

Submitted 04/2015

Accepted for publication 07/2015

\section{Abstract}

European Integration Studies No. 9 / 2015

pp. 235-243

DOI 10.5755/j01.eis.0.9.12810

(C) Kaunas University of Technology 
Nowadays creativity becomes important object of scientific research in such fields as innovations, education, business and others. The scientific research shows the complexity and multidimensity of creativity concept (Runco, M., 2014). Regarding to this, concept of creativity still remains important issue in many scientific works.

The explanation of creativity concept was changing constantly. For instance, first research on creativity analysed this concept in individual level. Later research focuses on cognitive level and analyse why individuals behave creatively. The research from 1990s started to analyse creativity in sociocultural approach. Before the 1980s creativity was treated as occasionally important to organizations success. However nowadays creativity is understood as essential for organizations (Sawyer, R.K., 2014).

The year 2009 was announced as the Year of Creativity and Innovations in European Union. With this initiative Europe tried to strengthen awareness of significance of

creativity in the context of individual, social as well as economic progress. In European level it is recognized the importance of creativity in innovation stimulation which are crucial in knowledge based economy. For instance, in the communication "Putting knowledge into practice: $A$ broad-based innovation strategy for the EU" it is stated that "without education as a core policy, innovation will remain unsupported. It must promote talent and creativity from an early stage". In a strategy for smart, sustainable and inclusive growth Europe 2020 the creativity of people is mentioned as the strength of Europe which can help to succeed.

EU initiatives show that creativity is emphasized not only in cultural field, but in education as well. EU seeks to stimulate creativity and supports the idea, that persons who act in creativity stimulating cultural, social and economic environment creates more innovative and creative products.

Much more, creativity and creative thinking is recognized as the competence of 21 century which is important concequence for successful activity in today's labour market (Gonzalez, J., et. al., 2007, Berdrow, I., Evers, E.T., 2011; Andrews, J., Higson, H. 2008; Ananiadou, K., Claro, M., 2009; van der Velden, R., 2013; Kang, M. et. al., 2010 and others).

Nowadays creativity is treated as essential for organizations (Sawyer, R.K., 2011). Sawyer, R. K.(2011) defines several reasons why creativity should be analyzed:

1 for identification and realization of individ- 3 for problems solving with creative responses; ual creativity;

2 for dealing with changing society;

4 for positive experience;

5 for effective education.

Creativity in business organizations was analysed by Amabile, T.M., (1998), Bilton, C., (2007), Seidel, S., Rosemann, M., Becker, J. (2008) and others. Despite of this research, there is still open question - how the creativity can contribute to the success of business organisations? This article is devoted for searching answer for this question.

The aim of this paper is to determine the directions of use of creativity in business organisations in order to cope with hyper competitiveness in nowadays business environment. In order to achieve this aim, the following objectives have been set:

1 to present evolution of the conception of 3 to identify the factors which encourage the creativity; development of creativity in organisations;

2 to cristalyzed out the concept of creativity;

he research method used: in-depth analysis of scientific literature, synthesis. 
Creativity is a broad concept, which is often used in science, business organizations, in daily human activities. Recently, this concept is used to explain almost everything - starting with global competition and information wars and ending with lifestyle and predominance of creative culture (Augustaitis, A., 2010). Martin, P. (2010) states that concept of creativity "has become a modern mantra" and are used in many problems solving. In order to coherently explore the object of this paper, the conception of creativity and its peculiarities and features are being further analysed.

The word to create comes from the Latin word creatus form creare, which means "to do or to make something". Historical analysis shows that this concept started up trying to explain the creation and existence of the world. The concept of creativity has been varying since its appearance (see figure 1).

Analyzing the above given illustration it is noticed that the concept creativity had not been

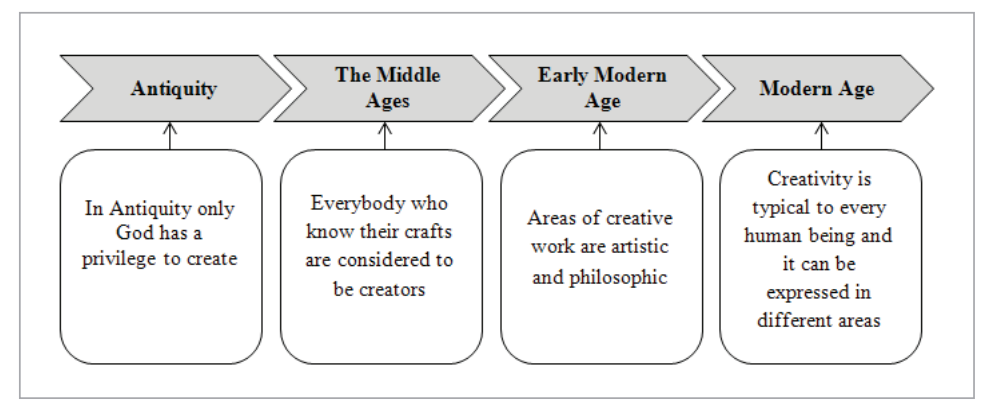
understood as a human creativity for a long time. According to the Antiquity thinker Plato, only God had the privilege to create and the whole earthly creation was only a mimetic art (Bukantiene, J. et al., 2013). Till the 16th century the ancient approach to creativity as a creation had dominated in the Western Europe. Everybody who knew their crafts were considered to be creators, artists. In the Renaissance period, unlike in the Middle Ages, a human with his creative powers was equated to God the Creator. A rise of such miscellaneous personalities like Leonardo da Vinci or Michelangelo, who were actively acting in many areas of culture, has influenced such situation. However, until the end of the 19th century creative powers were unambiguously attributed to the very precise field of human activity - artistic and philosophical creation. Inventors, scientists were not described as creative people. In the middle of the 20th century, when intensive researches of creativity started to be developed, it was acknowledged that creativity in one or another level is typical to everybody and can occur in various fields: science, art, household, communication and others. The provision, that creative activity was not an exceptional phenomenon and people of different age or profession can be creative, settled over.

To sum up, creativity as such phenomenon has already been recognized in the early cultures of the world, however, even then it was not understood uniformly. In ancient times God was considered to be the only creator. Later the creator was considered to be a person, who knew his crafts. Only in Modern Age it was started to consider that everybody can be a creative person and express himself in various areas.

Nowadays so often heard word creativity is understood variously. Scientists of various fields, such as philosophers, psychologists, sociologists, educators analyse the concept of creativity and its related problems. Creativity was started to be intensively explored sixty years ago, but until now its general conception has not been agreed.

According to Dumčienè, A., Lapienè, D. (2012) quite broad variety of conceptions, such as creativity, creative process, creative thinking is used to describe the studies of creativity. In table 1 it is presented different understanding of the creativity concept.

Authors, mentioned in the table above, provide with a distinctive description of concept creativity, emphasizing new characteristic and features. According to Wallas, G. (1926) creativity is the

\section{Evolution of the conception of creativity}

Figure 1

Evolution of the conception of creativity 


\begin{tabular}{|c|c|c|c|}
\hline \multirow{5}{*}{$\begin{array}{r}\text { The definition of } \\
\text { creativity }\end{array}$} & Author & Year & Definition \\
\hline & G. Wallas & 1926 & Creativity is the main force of human evolution. \\
\hline & T. Amabile & 1996 & Creativity is creation of new and useful ideas in any field. \\
\hline & A. Petrulytè & 2001 & $\begin{array}{l}\text { Creativity - the tendency of an individual to a new, original or innovative composition, } \\
\text { designing or thinking of something. }\end{array}$ \\
\hline & $\begin{array}{l}\text { R.Tickards } \\
\text { and F. Xu }\end{array}$ & 2007 & $\begin{array}{l}\text { Creativity is the process, when individuals, their groups generate ideas, which are } \\
\text { new and useful for these individuals or groups as well as other members of the field } \\
\text { of their activity. }\end{array}$ \\
\hline
\end{tabular}

main force of human evolution, because only the person who used this ability was able to adapt to a rapidly changing environment. Amabile, T. (1996) proposes that creativity is creation of new ideas. However, given definitions also have common similarities. "Flexible thinking and fluently developed ideas are important components of the definition of creativity. However, the most important feature of creativity is originality. Creative work is original, appropriate, reasonable and in a sense elegant or just good. So, creativity is a talent or activity, the result of which is ideas, theories, products of art or science." (Gage, N. L., Berliner, D.C., 1994)

Despite of different understanding of creativity concept, it is agreed that creativity is an ability to discover something new, to adapt the available knowledge purposefully and solve the problems originally, flexibly and effectively. Creativity is a steady encouragement to solve arisen problems in a productive way and to look for innovations.

Further analysis of the creative elements is important to determine what factors influence their expression, in what level or field they come through. Therefore, it is important to analyse this concept, using the models of creativity framed by scientists, by separating into different types.

Maslow, A. (1968) emphasizes improvisation and inspiration. From the psychological point of view, he proposes that human evolution, mental health and talent ensure high performance of creativity. Later, after accomplished research it emerged that it could not be adapted to each person. Famous painters Wagner and Van Gogh, who were characterised for their extraordinary creativity, proved that, however, at the same time their mental health state was unstable. As a result, Maslow, A. (1968) distinguished two types of creativity. One of them is a creativity of a special talent, which comes through independently of the personal health and well-being. It is the creativity of genius, also called the creativity with big $\mathrm{C}$. Contrary to the first type, creativity of self-realization characterize such individuals, which have excellent state of mind. This type of creativity can come through not only at the level of art, but at any human activity. It is creativity with little C.

According to Maslow, A. (1968) individuals with a high level creativity of self-realization are used to do everything creatively. Such group of people has a higher than average level of spontaneity, expressiveness, naturalness. They are also less controlled, therefore, they feel less uncomfortably and easily express their ideas and they are less worried about the surrounding opinions (Starko, A. J., 2010). Maslow, A. (1968) defines such creativity as a "fundamental feature, which is inherent from human nature, that is brought by everyone or at least the vast majority of people at birth, and which is often suppressed and lost during human inculturation." (Maslow, A., 1968)

Maslow, A. (1968) emphasizes the importance of self-expression in human life. Creativity is typical to each person and it is related with mental health. According to this understanding, creativity can be divided into two groups: creativity of special talent and creativity of self-realization. It is also possible to say that knowledge, skills, motivation, personal features and social environment is also typical to the classification of creativity. 
According to psychologists, in order to come through for an individual creativity, a person must have creative features. Different authors name different features, which are even contradictory one to another and which are typical to creative personality.

After the analysis of the elements proposed by authors, a new model of the features of creative personality was created. The first feature is originality. It is understood as the ability to think keeping to the subject or to have unusual ideas. Original people are known for a free thinking. It is a creation of original, absolutely new, unique or exclusively different ideas. Another feature is facility, which is understood as the ability to express thoughts fluently. The more time we have to create ideas, the bigger quantity and better quality is achieved. It is a smooth creation of ideas which would increase the amount of possible solutions. One more feature of creative personality flexibility. It is an ability to see the idea from different perspectives and ability to see different solutions out of one problem. Another feature is specification, which is understood as the ability to differentially and intensive analyse the problem. It is an essential requirement that it would be possible to plan in advance how the problem would be solved. The last of the features is imagination. It is the ability to dream, invent, see, and understand new ideas or creations, to be inventive. It is closely related with the ability to associate.

The input of creativity to economic success is analyzed in various research (Bobirca, A., Draghici, A., 2011; Sacchetti, S., Sugden, R., 2007; Sherwood, R. M., 1999; Yusuf, S., 2009).

Yusuf, S. (2009) presented the correlation between creativity and economic performance. It is presented in figure 2 .

Creativity is a crucial factor for innovations. Importance of innovation in nowadays organizations is unarguable. Innovations are the base for increasing productivity in nowadays knowledge based economies. Undoubtedly, innovations raises from application of knowledge creatively. According to this, there could emphasized two importartant factors:

_ Creativity;

_ Knowledge.

Creative organization is

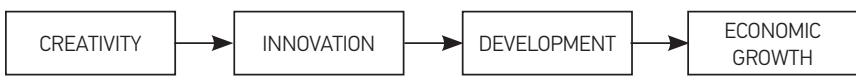

"characterized by native indi-

vidual creativity and competence, generates and uses the intellectual capital, create and realizes creative products, in such a way receives economic benefit and makes certain of competitive advantage" (Girdauskiene, L., 2011). Process, products, employees as well as work environment in such organizations is characterized as creative.

Business organizations which want to remain in today's competitive struggle, must always expand and improve. One of the main opportunities to do that is to allow employees to express their creativity at work. Each organization should understand that creative worker helps the organization to expand, improve and remain competitive in the market. This is particularly true when creativity becomes a part of the culture of the organization and employees are allowed to see particular things not according to the stereotypes.

According to the scientific literature the new model of creative environmental assessment was created. This model consists of three basic factors, which make influence on creativity in organization and each of these factors has individual elements (see figure 3).

The encouragement of organization is understood as an attention of organizational management structure and organizational climate. Therefore, it is important to understand the conception and features of the elements the encouragement of organization. One of elements encouraging the creativity in organizations is organizational structure. It is a particular set of means to divide work

\section{Elements which promote creativity in organizations}

Figure 2

Creativity and economic performance 
Figure 3

Model of elements encouraging creativity of organizations

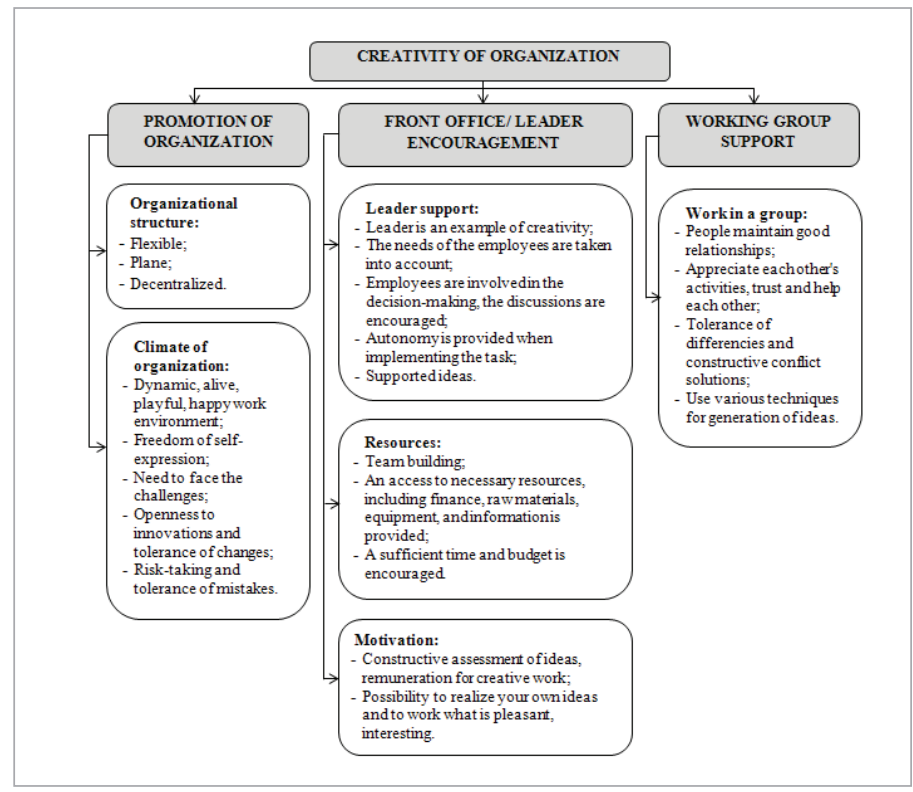

than centralized system, when everything is decided by the front office, while the divisions or departments do not have the possibility to make decisions.

Another encouraging element of the organization is organizational climate. Scientists researching creativity in organizations emphasize that when creating a favorable work environment for organizations, it is important to consider the same components which are necessary for individual creativity to come through.

Creating this model an attention was paid to the components identified by Ekvall, G. (1987). These components have an impact on creativity:

_ Challenge. People facing with big challenges have internal motivation to contribute to the organization. They find joy and meaning in their work and intend a lot of energy;

_ Environment. In such environment which encourages risk, new brave decisions can be made, even not knowing their result or finding oneself in unpleasant situation;

_ Dynamism and liveliness are the characteristics which define the events of organization life. Innovation, changes of way of thinking and new ways to solve the problems are frequent in dynamic situations. The atmosphere is alive and full of positive energy;

_ Confidence and openness define emotional safety of mutual relationship. In a high level of mutual confidence, each person in the organization can present their ideas and opinions. Initiatives can be taken without fear to receive negative emotions or to be mocked in case of failure. Communication is open and candid;

Playfulness and humour means spontaneity and abandon. Free atmosphere shows that the organization takes a high rank in terms of this factor.

According to Ekvall, G. (1996) creative climate is defined by three creative climate factors: behavior, feelings and attitudes. Therefore, it is possible to say, that organisational culture is characterized by certain specific cultural norms accepted by the majority, which encourage creativity in organization.

One more creative aspect in organization is front office or leader encouragement. This phenomenon includes the following factors:

_ Leader support. The leader sets the objectives, supports working group, estimates an individual contribution to work and shows trust in working group. It depends on a working group if workers will be involved in decision-making; 
_ Resources. The leader controls the formation of organization budget, decides workers hiring and firing cases, forms teams, sets priorities;

_ Motivation. Leader motivates and evaluates employees, suggests the objectives and vision of organization.

In order to better understand mentioned factors which depend on the leader, forming elements of each of them are discussed. The first factor is leader support. One of the most important factors that determines the existence of a favourable environment for creativity, is front office / leader favour and support. It could be emphasized that exactly the leader is responsible for creativity in organizations.

The role of a head as a leader has an important position for the existence of creative environment. The actions of the leaders are important not so much for the direct result, but also for signals about the desired behavior sent to other employees. Vision of the leader is the main factor in supervision of the creative persons. The vision of the leader reflects what could be and should be the future of organization.

Liberty, support of ideas and discussions are three factors depending on the leader and determining the creativity in organizations (Ekvall, G., 1986). Liberty is described as independence of human behavior in organization. In such a workplace where a lot of freedom is given, employees take the initiative to obtain and share information, the possibilities to try new fields are made. Organizations, which encourage discussions, listen to the opinions of employees, people are happy to offer their ideas.

Creativity is encouraged by such style of the leadership which supports the ideas of employees, takes into account their needs. If a leader criticizes employee, it is only in order to advise and not to humiliate. Thus the discussions are encouraged. Conversely, a high level of control, which is characterized by a vigilant supervision of inferiors, strict rules, exclusion of employees from decision making, considerably reduces the existence of an environment favorable for creativity.

Another group of elements of front office / leader encouragement factors is resources. Creativity also requires organizations to make strategic decisions considering human resources. Cook, P. (1980) considers that creative organizations must fight for attraction improvement and maintenance of creative talent, if they want to remain competitive. Creative organizations must try to employ people who desire to learn and ready to take the risks. Working groups should reflect the variety of skills and consist of individuals who trust and communicate with each other when generating various ideas (Amabile, T., 1987). Leaders must adapt the workplace which reflects the employee's experience and skills in creative thinking, to inspire an appropriate motivation.

In order for organization to be creative, it is especially important to improve and save its human resources. In the analyzed literature the usually importance of time and money is usually mentioned, as influencing factors that can support or conversely restrict creativity. When employee is given an insufficient time to experiment, he may unwittingly make mistakes on the way of creative process (Amabile, T., 1998). Restriction of resources can restrict creativity, because employees will be busy for a longer time searching for additional resources, rather than developing new products or services. According to Ekvall, G. (1986), time for ideas is the time that can be used by people for the development of new ideas. According to Amabile, T. (1998), leaders have to provide financial, human, time and other necessary resources which are necessary for the team to generate creative solutions.

One more group of elements of front office / leader encouragement factors is motivation. Motivation can be described as one of the most important factors which determine people behavior. It is like an internal load, which encourages to try and implement the aims. Motivation is very important for creative activity. According to Zakarevičius, P.(2003) motivation is a very important element of personnel management. Motivation of activity is an action which encourages employees to better 
perform their jobs (Zakarevičius, P., 2003). Researches have shown that supportive, informative evaluation can increase motivation, which mostly contribute to creativity (Deci, Ryan 1987). Creativity would increase, if they receive an award, which is understood as a kind of bonus, confirmation of competence, which may take a form of financial award or verbal compliment (Amabile, T., 1986).

Working group support is the third factor encouraging creativity in the organization. General objectives, settled norms, mutual relations influence the creativity of organizations. Organizations can easier come up with some new idea than individuals, however, a team work is one of the factors which influences creativity and affetct creative productivity (Grakaskaute - Karkockienè, D., 2006).

In the majority of modern organizations teams unify employees of unequal qualifications, different experiences and various attitudes. A group as well as individual creativity is affected by many factors: climate of the group, individual creativity and ability to work in a group. Creativity in the organization is encouraged by working group support, which comes through when people maintain good mutual relations, are open to new ideas, constructively assess each other's activities, trust and help each other and are committed to the work they perform. Psychologists who research working group influence on creativity observed that the work in group, especially when the creative problems are being solved, is more effective than individual work. VanGundy A. B. characterizes some advantages of work in groups: "the scope of knowledge is expanded when working in group; less mistakes are made; more unique ways of solving problems are created; participants are more pleased with their decisions; efficiency of application of decisions increases; less afraid to risks; more various and higher-quality ideas are generated; decisions are rejected more quickly, mistakes are observed; employees take more control to their behaviour, are more interested in task" (Grakaskaute - Karkockienè, D., 2006).

Final Insights

Analysis shows that understanding of creativity concept was changing constantly. According to the complexity and multidimensity of this concept, there are a lot of definitions of this phenomenon. Despite of various understanding of creativity concept, it could be stated that creativity is an ability to discover something new, to adapt the available knowledge purposefully and solve the problems originally, flexibly and effectively.

The individual creativity is one of main factors which influence the expression of creativity in higher levels such as organizations and society as well. Creativity is often associated with different human features and abilities. Creative personality from one simple idea or suggestion is able to create more ideas, thoughts and creations. Scientists, who analyse the creativity, identify its different features. The analysis of the proposed models also indicates the similarities: originality, facility, flexibility, specification and imagination.

Various authors very differently classify factors of creativity of organizations, therefore, new model of actions, which encourage creativity of organizations, was created. That model consists of organization encouragement, front office / leader encouragement and work group support.

Countries educational systems should be orientated to creativity as well. Much more, the importance of creativity should be understood in business sector as well as in government institutions, because government has the exceptional power to trigger the changes in business environment.

\section{References}

Amabile, T. M. (1998). How to Kill Creativity, Harvard Business Review, 76 (5)/

Amabile, T.M. (1987). Creativity in the R\&D Labaratory. Technical Report number 30. Greensboro, NC: Center for Creative Leadership;

Amabile, T.M., (1996). Creativity and Inovation at organizations. Harvard Business School.
Ananiadou, K., Claro, M. (2009). 21st century's skills and competences for New Millennium Students in OECD countries. Paris, France: Centre forEducational Research and Innovation (CERI) - New Millennium Students. http://dx.doi. org/10.1787/218525261154

Andrews, J., Higson, H. (2008). Graduate Employability, 'Soft Skills' Versus 'Hard' Business 
Knowledge: A European Study, Higher Education in Europe, 33:4, 411-422. http://dx.doi. org/10.1080/03797720802522627

Augustaitis, A. (2010). Kūrybinis žinojimas kompleksinėse aplinkose: kūrybiškumo sudaiktinimas, medijavimas ir vizualizavimas. Vilnius: Lietuvos mokslu akademijos leidykla;

Berdrow, I., Evers, F.T. (2011). Bases of Competence:A Framework for Facilitating Reflective Learner - Centered Educational Environments. Journal of Management Education, vol.35, no.3. http://dx.doi.org/10.1177/1052562909358976

Bilton, C. (2007). Management and creativity: From creative industries to creative management. Blackwell Publishing.

Bobirca, A., \& Draghici, A. (2011). Creativity and economic development. World Academy of Science, Engineering and Technology, (59), 887-892.

Bukantienè, J., Girdzijauskienè, R., Jarienè, R., Penkauskienè, D., Sruoginis, L. V. (2013). Mokiniu kūrybiškumo ugdymo lietuvių (gimtosios) kalbos pamokose metodika. Vilnius.

Cook, P. (1998). Privatisation in the UK: Policy and Performance. Edited by Parker, D. , Manchester University Press; http://dx.doi. org/10.4324/9780203058954.ch12

Deci, E. L., Ryan, R. M. (1987). The support of autonomy and the control of behavior. Journal of Personality and Social Psychology, 53(6), 1024-1037. http://dx.doi.org/10.1037/0022-3514.53.6.1024

Dumčienè, A., Lapėnienè, D. (2012). Kūno kultūros mokytoju kūrybingumo ugdymas. Kaunas: LKKA;

Ekvall, G. (1987). The Climate Metaphor in Organization Theory. In Bass, B. M. and Drenth, P. J. D. with Weissenberg, P. (eds.), Advances iin Organizational Psychology: An International Review. Beverly Hills: Sage, CA, psl. 177-190;

European Commission (2006). Putting knowledge into practice: A broad-based innovation strategy for the EU. Retrieved March 14, 2015, from Internet : http://eur-lex.europa.eu/legal-content/EN/TXT/ PDF/?uri=CELEX:52006DC0502\&from=EN

Gage, N. L., Berliner, D. C. (1994). Pedagoginè psichologija. Vilnius: Alma litera;

Girdauskienè, L. (2011). Ar reikia kūrybinès organizacijos lyderiams ugdyti darbuotojų lojalumą? Ekonomika ir vadyba

Gonzalez, J. et al. (2007). Reflections on and outlook for higher education in Latin America. University of Deusto.

Grakaskautè-Karkockienè, D. (2003). Kūrybos psichologija. Vilnius: Logotipas;

Yusuf, S. (2009). From creativity to innovation. Technology in Society, 31(1), 1-8. http://dx.doi. org/10.1016/j.techsoc.2008.10.007

Kang, M. et al. (2010). Developing an Educational Performance Indicator for New Millennium Learners. Journal of Research on Technology in Education. Vol.43., No.2 pp. 157-170. http://dx.doi.org/10 $.1080 / 15391523.2010 .10782567$

Martin, P. (2010). Making Space for Creativity. University of Brighton. Creativity Centre.

Maslow, A. H. (1968). Toward A Psychology of Being, New York: D. Van Nostrand Co., Second Edition;

Runco, M. A. (2014). Creativity: Theories and themes: Research, development, and practice. Elsevier.

Sacchetti, S., \& Sugden, R. (2007). Creativity and Economic Development.Biannual International Festival of Creativity and Economic Development, Gambettola, Italy, May, University of Birmingham, mimeo, March.

Sawyer, R. K. (2011). Explaining creativity: The science of human innovation. Oxford University Press, 2011.

Seidel, S., Rosemann, M., \& Becker, J. (2008). How does creativity impact business processes?.

Sherwood, R. M. (1999). Human Creativity for Economic Development: Patents Propel Technology. Akron L. Rev., 33, 351

Starko, A. J. (2010). Creativity in the Classroom: Schools of curious Delight. New York: Routledge;

van der Velden, R., (2013). Measuring Competences in Higher Education: What Next? In: S. Blömeke, 0. Zlatkin-Troitschanskaia, C. Kuhn, \& J. Fege (Eds.), Modeling and Measuring Competencies in Higher Education. Rotterdam: Sense Publishers. http://dx. doi.org/10.1007/978-94-6091-867-4_15

Wallas, G. (1926). The Art of Thought. New York: Harcourt Brace.

Zakarevičius, P. (2003). Pokyčiai organizacijose: priežastys, valdymas, pasekmès. Kaunas: VDU;

\section{BERTA DAUKNYTÉ}

Master of International Business

Kaunas University of Technology Faculty of Social Sciences, Artand Humanities Institute of Europe

\section{Address}

E-mail: berta.dauknyte@ktu.lt

\section{About the authors}

Kaunas University of Technology Faculty of Social Sciences, Arts and Humanities Institute of Europe

\section{Address}

E-mail: jurgita.baryniene@ktu.lt 